\title{
Evaluation of Antimicrobial Activities of Garcinia latissima Miq. Stem Bark Extract
}

\author{
Neneng Siti Silfi Ambarwati ${ }^{1}$, Berna Elya ${ }^{2}$, Amarila Malik², Muhamad Hanafi ${ }^{3}$ \\ 'Faculty of Engineering, UniversitasNegeri Jakarta, Jl. Rawamangun Muka, East Jakarta, INDONESIA. \\ 2Faculty of Pharmacy, Universitas Indonesia, Kampus UI Depok, Depok 16424, INDONESIA. \\ ${ }^{3}$ Center for Chemistry Indonesian Institute of Sciences, INDONESIA.
}

\begin{abstract}
Introduction: To evaluate the antimicrobial activities of hexane, ethyl acetate, and methanol extracts from the stem bark of Garcinia latissima Miq. Method: The G. latissima Miq. was collected from Bogor. This study uses multilevel maceration extraction methods. The antimicrobial activity was determined by the good diffusion method and the broth dilution method. Result: The ethyl acetate extracts of stem bark were active against Bacillus subtilis, aeruginosa Staphylococcus aureus, and Ps aeruginosa, and virtually inactive against Escherichia coli, Candida albicans, and Trichophyton mentagrophytes. The methanol extracts of stem bark were active against $B$. subtilis and $S$. aureus, and virtually inactive against $E$. coli, P. aeroginosa, $C$. albicans, and T. mentagrophytes. The hexane extracts of stem bark were inactive against $B$. subtilis, $S$. aureus, E. coli, P. aeroginosa, C. albicans, and T. mentagrophytes. The $2 \%$ methanol extracts of G. latissima Miq. stem bark showed the maximum zone of inhibition against $B$. subtilis $(10.70 \pm 0.638 \mathrm{~mm})$, followed by the methanol extracts of G. latissima Miq. stem bark against $S$. aureus $(10.38 \pm 0.653 \mathrm{~mm})$. $2 \%$ Ethyl acetate extracts of G. latissima Miq. stem bark exhibited a maximum zone of inhibition against $B$. subtilis $(10.35 \pm 0.867 \mathrm{~mm})$ followed by $P$. aeruginosa $(10.07 \pm 0.971 \mathrm{~mm})$. The results of the antibacterial activity
\end{abstract}

showed that the $\mathrm{MeOH}$ extract of $\mathrm{G}$. latissima Miq. stem bark exhibited activities against $B$. subtilis (MIC/MBC $=625 \mathrm{ppm} / 2500 \mathrm{ppm}$ )and $S$. aureus $(\mathrm{MIC} / \mathrm{MBC}=2500 \mathrm{ppm} / 5000 \mathrm{ppm})$. The ethyl acetate extract of $\mathrm{G}$. latissima Miq. stem bark exhibited activities against $P$. aeruginosa (MIC/ $\mathrm{MBC}=5000 \mathrm{ppm} / 5000 \mathrm{ppm}$ ) and $\mathrm{B}$. subtilis (MIC/MBC $>5000 \mathrm{ppm} / 5000$ ppm). Conclusion: The results of the present study revealed most valuable information and also support the continued sustainable use of $G$. latissima Miq. stem barks in a traditional system of medicine.

Key words : Garcinia latissima, Antimicrobial activities, Stem bark extract, Hexane, Ethyl acetate, Methanol.

Correspondence:

Neneng Siti Silfi Ambarwati

Faculty of Engineering, Universitas Negeri Jakarta, Jl. Rawamangun Muka, East Jakarta, INDONESIA.

Phone no: 6281399439923

Email: neneng_ambarwati@yahoo.co.id

DOI: 10.5530/jyp.2017.1s.15

\section{INTRODUCTION}

Genus Garcinia comprises 180 species. ${ }^{1}$ Clusiaceae (Guttiferae), a largely tropical woody is a family of a 27 genera and 1,090 species, largely restricted to lowland tropics. ${ }^{2,3}$ Many Clusiaceae from the New World tropics produce resin, ${ }^{3}$ the yellow sap that is used a source of gamboge paint and varnish, e.g. G. mangostana, G. dulcis (Thailand, India, Sri Lanka), G. hanburyi (Thailand), G. morrella (India). Some of this family is known as traditional medicine, for example, the roots of G. picorriza Meg. andG. atroviridis as fever-lowering drugs, juice leaves given to the woman who runs the maternity, G. cowa Roxb. has been used in Thai folk medicine for its antipyretic property. ${ }^{4,5}$ Extracts of G. mangostana showing inhibitory effects against the growth of $S$. aureus. ${ }^{6}$ Extracts derived from leaves of $G$. daedalanthera showed inhibitory activity against a-glucosidase enzyme significantly, with IC50 value of $2.33 \mathrm{ug} / \mathrm{mL} .{ }^{7}$ Garcinia sp. (Guttiferae) is a reach source of xanthones and various bioactivities of xanthones. ${ }^{8}$ Constituents of EtOH extracts of the stem bark of $G$. latissima Miq., collected in Central Province of Papua New Guinea were studied. ${ }^{9}$ A novel four new pyranoxanthones named latisxanthone-A, $-\mathrm{B},-\mathrm{C}$, and $-\mathrm{D}$ were isolated. ${ }^{9}$ Latisxanthone-C might be valuable antitumor promoters. ${ }^{8} \mathrm{MeOH}$ solubles of the Papua New Guinea Garciniasps. stem barks extracts showed potential antibacterial activity Bacillus subtilis and Staphylococcus aureus. ${ }^{10}$ In the area of Papua, there are plants that are empirically has been used as itchy medicine by the local community, i.e. Garcinia latissima. The other potential activity of compounds derived from Garcinia latissima Papua Indonesia has not been studied yet and the data are still limited. Therefore, it will be investigated the biological activities of Garcinia latissima plant originating from Indonesia's Papua for antimicrobial. The aim of this study it was to develop the native flora of Papua, Indonesia in an attempt to obtain novel drug mainly for an anti-microbial active compound as an alternative to antibiotic drugs which are now resistant to many antibiotics. We examined the anti-microbial activity of hexane, ethyl acetate, and methanol extracts of stem bark of $G$. latissimain this study and as well the minimal inhibitory concentrations of the active extract. This plant is found in Seram Maluku and Papua but has been cultivated in Bogor Botanic Garden; the local name of Garcinia latissima Miq is Dolomagota (Maluku). ${ }^{11,12}$

\section{MATERIAL AND METHODS}

\section{Materials}

Garcinia latissima Miq. stem bark were collected from Center for Plant Conservation Botanic Gardens, Indonesian Institute of Sciences. They were identified at The Center for Plant Conservation Botanic Garden, Indonesian Institute of Sciences.

This is an open access article distributed under the terms of the Creative Commons Attribution-NonCommercial-ShareAlike 4.0 License, which allows others to remix, tweak, and build upon the work non-commercially, as long as the author is credited and the new creations are licensed under the identical terms. 


\section{Methods}

\section{Extract Preparation}

Preparation of stem bark material begins with collecting the stem bark $(5.008 \mathrm{kgs})$ from the healthy plant which is not contaminated with fungi, bacteria, or viruses collected. Determination of plants was conducted to determine the classification of these plants. ${ }^{13}$ After washing to remove dirt, a small cut of simplicia were dried at room temperature, or in the oven, to prevent microbial fermentation and degradation of metabolites; besides to minimize chemical reactions that can occur as a result of ultraviolet rays from direct sunlight. Dried material was stored in a sealed container in a cool, dry place. Storage for too long must be avoided, as it can decipher some of the compounds. Milling was done to increase the yield of the extract by expanding the surface area of the sample and solvent penetration into cells. ${ }^{13}$ This study uses multilevel maceration extraction methods. $2.116 \mathrm{kgs}$ dried powdered stem bark material was extracted by repeated maceration with $(5 \mathrm{x} 8 \mathrm{~L})$ for 24 hours at room temperature using various solvents: hexane, ethyl acetate, and methanol in a row. The solvents used were a technical level purchased from PT Duta Pratama Chemika, Bogor, Indonesia and was distilled before used. After extraction, the extracts were separated from the solvent by filtration through Whatmann No. 1 filter paper and the filtrate was evaporated to dryness under reduced pressure using rotary evaporator. The residue (crude extract) was collected and stored at $4^{\circ} \mathrm{C}$ before used. ${ }^{14}$

\section{Phytochemical Screening}

The extracts of Garcinia latissima Miq. stem bark were qualitatively tested for detection of tannins, saponins, flavonoids, anthraquinons, terpenoids, and alkaloids following standard phytochemical procedures. ${ }^{15,16}$ The experiment was conducted in triplicates.

\section{Antimicrobial Activity: Inhibition Zone Test}

The antimicrobial screening was carried out using the well diffusion method. Four bacterial strains were used in first step as qualitative test in this study, i.e. Staphylococcus aureus ATCC 25923, Escherichia coli ATCC 25922, Pseudomonas aeroginosa ATCC 27853, and Bacillus subtilis ATCC 6633, whereas two fungal species Candida albicans and Trichophyton mentagrophytes were also used. The microbial were obtained from the collection of Laboratory of Microbiology and Biotechnolgy, Faculty of Pharmacy, Universitas Indonesia. Microbial stock cultures were cultured in nutrient agar for incubation at $37^{\circ} \mathrm{C}$ for 24 hours. ${ }^{17}$ The discs of $6 \mathrm{~mm}$ were prepared using a Whatmann filter paper. One hundreds discs were obtained by punching and putting in glass petri dish and sterilizing in an autoclave at $1 \mathrm{~atm}, 121^{\circ} \mathrm{C}$ for $15-20 \mathrm{~min}$. The discs were impregnated with crude $100 \%$ extracts. In the second step, inhibition zone test only use the positive results from the first step, used $2 \%$ crude extracts in DMSO. This is a semi-quantitative test. Prepared discs containing the various fractions were carefully placed on the inoculated plates using a sterilized forceps in each case. The agar plates were then turned upside down and incubated at $37^{\circ} \mathrm{C}$ for $24 \mathrm{~h}$ in an incubator. ${ }^{17}$ The zone of inhibition against the selected pathogens was determined and recorded. Antimicrobial activity was evaluated by measuring the diameter of the inhibition zone (IZ) around the disc by using vernier. The antibiotic reference Gentamicin was served as positive control for S. aureusassay, Erythromycin was served as positive control for B. subtilisassay, Ciprofloxacin was served as positive control for P. aeruginosaassay, Amoxicillin was served as positive control for E. coli. ${ }^{14}$ Each disc can be loaded for $20 \mu \mathrm{L}$. The experiment was conducted in triplicates.

\section{Minimum inhibitory concentration/minimum bactericidal concentration assay}

The antimicrobial activity of the ethyl acetate extract of G. latissima Miq. stem barks was conducted against $B$. subtilisand $P$. aeruginosa, whilst methanol extract of G. latissima Miq. stem barks against B. subtilisand P. aeruginosa. Bacterial stock cultures were cultured in nutrient agar for incubation at $37^{\circ} \mathrm{C}$ for $24 \mathrm{~h}$. Bacterial stock cultures were sub-cultured in nutrient broth and was compared as judged by eyes, to reach estimated $0.5 \mathrm{Mc}$ Farland $\left(10^{9}\right.$ bacterium $\left./ \mathrm{mL}\right) .{ }^{17}$ This assay was determined by the broth dilution method. The minimum inhibitory concentration (MIC) was determined as the lowest concentration of test samples that resulted in a complete inhibition of visible growth in the broth. The minimum bactericidal concentration (MBC) was determined by plating out onto each appropriate agar plate. ${ }^{18}$

\section{RESULTS AND DISCUSSION}

Preliminary phytochemical group tests revealed that different extracts of Garcinia latissima Miq. stem bark contain tannins, saponins, alkaloids, and flavonoids (Table 1). The results of the antimicrobial efficacy of hexane, ethyl acetate and methanolic extracts of G. latissima stem barks are presented in Table 2. All of the extracts show the inhibition against the selected pathogens. The zone of inhibition of various extracts of $G$. latissima Miq. was compared to the commercially available standard antibiotic disc. The standard antibiotics showed positive results against the microbial. Erythromycin against B. subtilis $(25.55 \mathrm{~mm})$, gentamycin against $S$. aureus $(22.70 \mathrm{~mm})$, amoxicillin against E. coli $(23.85 \mathrm{~mm})$, ciprofloxacin against $(21.95 \mathrm{~mm})$. However, S. aureus, B. subtilis and P. aeruginosa were resistant to the hexane extracts of G. latissima Miq. stem bark. E. coli, C. albicans, and T. mentagrophytes were resistant to the ethyl acetate, hexane, and methanol extracts of G. latissima Miq. stem bark. The methanol extracts of G. latissima Miq. stem bark showed the largest zone of inhibition against $B$. subtilis $(10.70 \pm 0.638 \mathrm{~mm})$, followed by the methanol extracts of G. latissima Miq. stem bark against S. aureus $(10.38 \pm 0.653 \mathrm{~mm}$ ) (Table 3 ). Ethyl acetat extracts of G. latissima Miq. stem bark exhibited the largest zone of inhibition against $B$. subtilis $(10.35 \pm 0.867 \mathrm{~mm})$, followed by $P$. aeruginosa $(10.07 \pm 0.971 \mathrm{~mm})$ (Table $3)$. The results of the antibacterial activity showed that the $\mathrm{MeOH}$ extract of G. latissima Miq. stem bark exhibited activities against B. subtilis $(\mathrm{MIC} / \mathrm{MBC}=625 \mathrm{ppm} / 2500 \mathrm{ppm})$ and $S$. aureus $(\mathrm{MIC} / \mathrm{MBC}=2500$ $\mathrm{ppm} / 5000 \mathrm{ppm}$ ). The ethyl acetate extract of G. latissima Miq. stem bark exhibited activities against $P$. aeruginosa $(\mathrm{MIC} / \mathrm{MBC}=5000 \mathrm{ppm} / 5000$ $\mathrm{ppm}$ ) and B. subtilis (MIC/MBC > $5000 \mathrm{ppm} / 5000 \mathrm{ppm})$. Maceration method is suitable for both initial and bulk extraction. The main disadvantage of maceration is that the process can be quite time-consuming, can also comsume large volumes of solvents and can lead to the potential loss of metabolites. Some compounds may not be extracted efficiently if they are poorly soluble at room temperature. On the other hand, maceration is less likely to lead to the degradation of thermolabile metabolites. ${ }^{13}$ Solvent extraction has been performed by process selected. The physicochemical properties of some common solvents used in natural product extraction are as follows: polarity index of $n$-hexane 0.0 , polarity index of ethyl acetate 4.4, polarity index of methanol 5.1. The initial choice of the most appropriate solvent is based on its selectivity for the substances to be extracted. A selective extraction can also be performed sequentially with solvents of increasing polarity. ${ }^{13}$ Medicinal plants contain thousands of substances that could be used for therapeutic purposes. They are precursor for the synthesis of useful drugs and are safe to human health. ${ }^{14}$ The growing population concern about health problems has recently led to the development of natural antimicrobials to control microbial disease. The antimicrobial activity found in the plant extracts have been 
Table 1: Results of phytochemical screening of Garcinia latissima Miq. stem bark extracts in different solvents

\begin{tabular}{ccccc}
\hline Phytochemical & Test & Hexane & Ethyl acetate & Methanol \\
\hline Tannins & FeCl3 & - & - & + \\
& Gelatin & - & - & + \\
Saponins & Frothing test & + & - & + \\
Flavonoids & $\mathrm{Mg}+\mathrm{HCl}$ & - & + & + \\
Anthraquinons & Borntrager's & - & - & - \\
Terpenoids & $\mathrm{H} 2 \mathrm{SO} 4$ & - & - & - \\
Alkaloid & Dragendorff's & + & + & - \\
& Mayer's & + & + & - \\
& Bourchardat's & + & + & - \\
\hline
\end{tabular}

Table 2: Antimicrobial efficacy of various extracts of G. latissima Miq. stem barks

\begin{tabular}{cccc}
\hline \multirow{2}{*}{ Organisms } & \multicolumn{3}{c}{ Different solvent of G. latissima stem bark extract } \\
\cline { 2 - 4 } & Ethyl acetate & Hexane & Methanol \\
\hline B. subtilis & ++ & - & ++ \\
C. albicans & - & - & - \\
S. aureus & + & - & ++ \\
E. coli & - & - & - \\
P. aeruginosa & ++ & - & - \\
T. mentagrophytes & - & - & - \\
\hline
\end{tabular}

Antimicrobial efficacy: -, No inhibition; +, Zone of inhibition $<10 \mathrm{~mm}$ in diameter; ++ , Zone of inhibition $\geq 10 \mathrm{~mm}$ in diameter

Table 3: Antibacterial activity of $\mathbf{2 \%}$ stem bark extract of G. latissima Miq.- use Disc diffusion method

\begin{tabular}{ccccc}
\hline Microorganisms & $\begin{array}{c}\text { Ethyl acetat } \\
\text { extract } \mathbf{0 , 4} \\
\mathrm{mg} / \text { disc }\end{array}$ & $\begin{array}{c}\text { Methanol } \\
\text { extract } \mathbf{0 , 4} \\
\mathrm{mg} / \text { disc }\end{array}$ & $\begin{array}{c}\text { Hexane } \\
\text { extract } 0,4 \\
\mathrm{mg} / \text { disc }\end{array}$ & $\begin{array}{c}\text { Standard } \\
\text { antibiotic }\end{array}$ \\
\hline Bacteria & \multicolumn{4}{c}{ Diameter of Inhibition zone in mm (mean) } \\
\hline B. subtilis & $10.35 \pm 0.867$ & $10.70 \pm$ & 0 & $21.08 \pm$ \\
& 0 & 0.638 & & 1.928 \\
S. aureus & 0 & $10.38 \pm$ & 0 & $23.70 \pm$ \\
& & 0.653 & & 1.928 \\
P. aeruginosa & $10.07 \pm 0.971$ & 0 & 0 & $21.88 \pm$ \\
& & & & 0.511 \\
\hline
\end{tabular}

Mean of three replicate determination \pm SD; Standard antibiotic: Erythromycin $15 \mu \mathrm{g}$ for B. subtilis, Gentamycin $10 \mu \mathrm{g}$ for S. aureus, Ciprofloxacin $5 \mu \mathrm{g}$ for P. aeruginosa.

attributed to some of the secondary metabolites. ${ }^{14}$ Preliminary phytochemical screening revealed that different solvents of extract of Garcinia latissima Miq. contain tannins, saponins, flavonoids, and flavonoids (Table 1). The antibacterial activity of plant extracts was not only due to one main active chemical but to the combined action of additional other compounds. ${ }^{17}$ It is clear that the chemical structure of the antimicrobial agents found in higher plants belong to most commonly encountered classes of higher plant secondary metabolites. ${ }^{17}$ It was reported that the extraction with different types of solvents affect antimicrobial activity inhibition zone. ${ }^{19}$ Methods to detect antimicrobial activity can be clas- sified into three groups: diffusion, dilution, and bioautography. ${ }^{20}$ The advantage of the diffusion method is high suitability for screening pure substances. ${ }^{21}$ Diffusion method is a method that is using disc, holes, or cylinders for sample reservoirs. Dilution method was using a solution or suspension of microbes with a certain concentration. Dilution and diffusion methods can be used both antimicrobial and qualitative test for the determination of minimum inhibitory concentration (MIC) of the mixture (such as extracts) or the pure compound. ${ }^{22}$ G. latissima Miq. stem bark methanolic extracts showed the highest antimicrobial effect. The MIC and MBC values against B. subtilisare 625 and 5,000 ppm. The MIC and MBC values against $S$. aureusare 2,500 and 5,000 ppm. G. latissimaMiq. stem bark ethyl acetate extracts showed MIC/MBC values against $P$. aeruginosa5,000/5,000 ppm and against $B$. subtilis $>5,000 \mathrm{ppm}$.

\section{CONCLUSION}

The results of the present study revealed most valuable information and also support the continued sustainable use of G. latissima Miq. stem barks in traditional system of medicine. Moreover, a continuous and progressing research is to be conducted to prove the biological ingredients and test the safety, efficiency and to determine the types of compounds responsible for the antimicrobial effect of G. latissima Miq stem bark.G. latissima Miq. stem bark methanolic extracts showed good in vitro antibacterial effects especially against $B$. subtilis and $S$. aureus. The result presented here may explain the traditional use of this plant. ${ }^{17}$

\section{ACKNOWLEDGMENT}

The authors thank Center for Plant Conservation Botanic Gardens, Indonesian Institute of Sciences for providing plant material and the confirmation of plant authenticity. We are greatly appreciated the financial support from research grant Hibah PITTA 2016.

\section{CONFLICT OF INTEREST}

No conflict of interest are declared.

\section{ABBREVIATION USED}

G. latissima: Garcinia latissima; MIC: The minimum inhibitory concentration; MBC: The minimum bactericidal; ATCC: The American Type Culture Collection; IZ: The inhibition zone.

\section{REFERENCES}

1. Ilyas M, Kamil M, Parveen M, Khan MS. Isoflavones from Garcinia nervosa Phytochemistry. 1994;34(3):807-9.

2. Gustafsson MHG, Bittrich $V$, Stevens PF. Phylogeny of Clusiaceae Based on rbc L. Sequences. Int J Plant Sci. 2002;163(6): 1045-54.

3. Stevens PF. The Families and Genera of Fascular Plants. In: Flowering Plants 2007;9:48-66

4. Burkill HM. The Useful Plants of West Tropical Africa, Vol. 2, Royal Botanic Gardens, Kew (K), 1985.

5. Likhitwitayawuid K, Phadungcharoen T, Mahidol C, Ruchirawat S. 7-O-Methylgarcinone E from Garcinia cowa. Phytochemistry. 1997;45(6):1299-301.

6. Linuma M, Tosa $\mathrm{H}$, Tanaka $\mathrm{T}$, et al. Antibacterial activity of xanthones from guttiferaeous plants against methicillin-resistant Staphyloococcus aureus. J Pharm Pharmacol. 1996;48(2):861-5.

7. Elya B, Basah K, Mun'im A, Yuliastuti W, Bangun A, Septiana EK. Screening of Glucosidase Inhibitory Activity from Some Plants of Apocynaceae, Clusiaceae Euphorbiaceae, and Rubiaceae. J Biomed Biotechnol. 2012;1-6.

8. Ito $\mathrm{C}$, Itoigawa $\mathrm{M}$, Furukawa $\mathrm{H}$ et al. Xanthones as inhibitors of Epstein-Barr virus activation. Cancer Lett. 1998;132(1-2): 113-7.

9. Ito C, Miyamoto Y, Nakayama M, Kawai Y, Rao KS, Furukawa H. A Novel Depsidone and Some New Xanthones From Garcinia Species. Chem Pharm Bull. 1997;45(9):1403.

10. Rao KS. Antibacterial Activity of Some Medicinal Plants of Papua New Guinea Int J Pharmacogn. 1996;34(3):223-5.

11. Conservation R of III of SC for P. An Alphabetical List of Plant Species Cultivated in The Bogor Botanic Gardens, 2010. 
12. Xi-Wen L, Jie L, Robson NKB, Stevens PF, Clusiaceae (guttiferae), Flora of China, 2009, 13, 1-47.

13. Sarker SD. Latif Z. Gray Al. Natural Products Isolation Second Edition. New Jersey Humana Press. 2006.

14. Johnson M. Kalaiarasi V. Sivaraman A. Janakiraman N. Babu A. Narayani M. Phytochemical and Antibacterial Studies on Aristolochia tagala. Cham World J Pharm Res. 2014;3(2):2172-8.

15. Dep.Kes.R.I. Materia Medika Indonesia Volume VI, Jakarta, Departemen Kesehatan RI, 1995.

16. Fransworth NR. Biological and Phytochemical Screening of Plants. J Pharm Sci. 1995;22(3):226-76

17. Kochuthressia KP, Britto SJ, Jaseentha, Raphael R. In vitro Antimicrobial Evaluation of Kaempferia galanga L. Rhizome Extract. Am J Biotechnol Mol Sci. $2012 ; 2(1): 1-5$.
18. Jeong M-R, Kim H-Y, Cha J-D. Antimicrobial Activity of Methanol Extract from Ficus carica Leaves Against Oral Bacteria. J Bacteriol Virol. 2009;39(2):97-102.

19. Yeo YL, Chia YY, Lee CH, Sow HS, Yap WS. Effectiveness of Maceration Periods with Different Extraction Solvents on In-Vitro Antimicrobial Activity from Fruit of Momordica charantia L. J Appl Pharm Sci. 2014;4(10):16-23.

20. Tyihak E, Moricz AM. Ott PG. Biodetection and Determination of Biological Activity of Natural Compounds, In: Waksmundzka-Hajnos M., Sherma J., Kowalska T., eds., Thin Layer Chromatography in Phytochemistry, Vol. 99,Boca Raton, CRC Press, 2008, 193-213.

21. Chomnawang MT, Surassmo S, Nukoolkarn VS, Gritsanapan W. Antimicrobial effects of Thai medicinal plants against acne-inducing bacteria. J Ethnopharmacol. 2005;101(1-3):330-3.

22. Carroll KC, Butel JS, Morse SA, MietznerT. Jawetz, Melnick \& Adelberg's Medical Microbiology, 27 $7^{\text {th }}$ ed., New York, Mc Graw Hill Education, 2016.

Article History: Submission Date: 03-02-17; Revision Date: 20-02-17; Accepted Date:25-02-17.

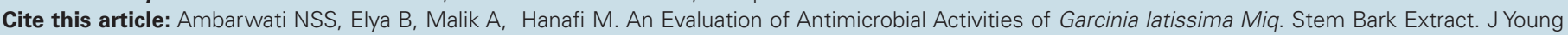
Pharm. 2017;9(1)Suppl:s56-s9. 